\title{
The standardization process of Louisiana French: issues and outcomes
}

\section{Nina Rioult ${ }^{1}$}

Abstract: The main goal of this article is to give a general overview on the standardization process of the French language in Louisiana. After examining the sociolinguistic situation of Louisiana French and discussing the notion of "standard language", following the definitions of Bagno (2011) and Milroy \& Milroy (1999), we will try to understand what recovers the notion of "Standard French". Thereafter, we will analyze how its introduction in Louisiana has triggered some issues on the linguistic norm to be used during the revitalization movement, which began in the 1960s, and how these debates influenced the French norm used nowadays in Louisiana.

Keywords: Standard language. Linguistic norm. Louisiana French. Revitalization.

\section{Introduction}

ntil today, Louisiana remains one of the states with the strongest
French heritage, a reminiscence of the French colonial empire in North America, that ended in the mid-XVIII ${ }^{\text {th }}$ century. Although the French language kept being spoken in Louisiana long after the leave of the colonial state, the language shift to English was almost complete in the $\mathrm{XX}^{\text {th }}$ century, so that the French language was considered strongly endangered. Yet, in the 1960s, a revitalization movement was launched, bearing the ambitious goal to restore bilingualism in the region. One of the critical points of the revitalization policy was the choice of the variety of French to be used in this process, and particularly the one to be taught in schools. More precisely, the core question was to know whether the Louisianan

1 Professeure de Français Langue Étrangère. 
institutions should use the already existing norm in French, labeled as Standard French, or create an own indigenous norm by standardizing one of the vernacular varieties of French. Thus, the aim of this article is to analyze this process and present its effects on the norm used in Louisiana nowadays. In order to understand these issues, we will first provide a sociohistorical overview of the French language in Louisiana and show the rich diversity of the French-speaking populations and the French language varieties present on the territory. Next, we will examine the concept of standard language and linguistic norm, and see its implications in the context of Louisiana. Finally, we will examine how this issue was handled during the beginning of the revitalization movement and see what its results are today.

\section{French in Louisiana: a sociohistorical overview ${ }^{2}$}

The history and profile of the francophone populations who inhabited this land is a rich, complex and diverse one. The main purpose of this section, mostly based on the thesis of Atran-Fresco (2014), is to provide a general overview of the very diverse French-speaking populations of Louisiana, who arrived at different times in this territory.

Until now, Louisiana has a strong francophone legacy. The French language was introduced in the XVII ${ }^{\text {th }}$ century, with the colonization of the territory by the French Kingdom. In 1682, the colony was named Louisiana, a tribute to the king of France, Louis XIV. Almost a century later, in 1762, the province was sold to the Kingdom of Spain and, in 1812, it became part of the newly independent United States. Even though the French colonial power left the territory in the XVIII ${ }^{\text {th }}$ century, the language continued to be used in different domains of the everyday life - included in the newspapers

2 Similar developments from this section can be found in the following paper: RIOULT, N. Louisiana French: A successful Revitalization? In: SAVEDRA, M.; ROSENBERG, P. Estudos em sociolinguística de contato, forthcoming. 
- so that French remained the majority language in the region, sustained by the constant arrival of several French-speaking people.

The Cajuns (Cadiens) are the descendants of Acadians (Acadiens), who were descendants of populations from western France (Poitou, Brittany). They had settled on the colonized French territory of Acadia (Nova Scotia, Canada,), until they were expelled from Canada after the territory was acquired by Great Britain, an episode known as "The great deportation" (Le grand dérangement, 1755-1763). Many of the Acadian exiles converged in Louisiana, forming an autonomous community now known as Cajun.

However, Cajuns were not the only French-speaking communities in Louisiana. In 1720, the first enslaved populations arrived from Africa and progressively adopted French language too. Besides, from 1791 onward, many refugees arrived from Haiti, where the Haitian revolution was started by the slave revolt. Among them, there were white settlers, their slaves, and also the "free people of color". The arrival of important numbers of persons from Haiti had an important impact on the fate of the French language in the region, as well as on the development of a creole culture.

Atran-Fresco (2014, p. 26) points that, in Louisiana, the term "creole" is polysemic. Indeed, in the XVIII ${ }^{\text {th }}$ century, the term could refer to the descendants of slaves who directly came from Africa, slaves from Haiti or "free people of color" (known as Black Creoles), but also to settlers from France, either plantation owners from Haiti, individuals directly arrived from France to seek economic opportunities or to flee the French Revolution (known as White Creoles). The population of White Creoles, that was mainly based in the city of New-Orleans, has been almost totally assimilated to the Anglo-Saxon American society. Thus, we observe that the French-speaking communities have very diverse sociocultural and historical backgrounds. This diversity is also reflected in the language, as the generic term "Louisiana French" refers to diverse linguistic varieties. 
At first sight, defining what is understood by 'Louisiana French' (LF) is not an easy task. Indeed, using a specific name directly points out a specificity. According to Bagno (2011, p. 371): "To give a name to a way of speaking, to label it as a 'language', is not an innocent act" ${ }^{3}$. According to Le Page (1980 apud ABOURETKELLER, )leads to its " "'processes, transforming the language into an object and giving it an iconic status. Thus, what does the fact of adding the word "Louisiana" to "French" imply? Isn't Louisiana French just French? If not, why? In the next paragraph, we will briefly present the main local linguistic varieties that have been identified in Louisiana. Indeed, the identification and definition of the spoken varieties of French has been crucial for the debate aroused during the French revitalization movement in Louisiana.

Valdman and Klingler (1997, p. 109) state that "Louisiana offers the most complex linguistic situation found in the Caribbean Rim". Several languages have been in contact for centuries and all have contributed to Louisiana's current linguistic complexity. We will focus on French and its three main identified varieties:

(1) Colonial French: this variety was the closest to standard French, spoken by White Creoles, this is the rich elite mainly settled in the city of New Orleans. This variety of French has practically disappeared (ATRANFRESCO, 2014, p. 97).

(2) Louisiana Creole (LC): this variety is a French-based creole spoken mostly by Black Creoles, but not only. According to Valdman and Klingler (1997, p. 111), LC is probably the French-based creole structurally closest to French. Although strongly endangered, this variety is still present in Louisiana.

(3) Cajun French (CF): According to Brown (1993 apud BLYTH, 1997, p. 26), it is "the variety spoken by the descendants of the Acadians,

3 Dar um nome a um modo de falar, rotulá-lo de 'língua', não é um ato inocente. 
Native Americans, and immigrants absorbed by the group, it is mutually intelligible with International French".

Today, only LC and CF remain in Louisiana. However, these distinctions reflect only partially the situation, since the distinction between those varieties is not always clear. For instance, LC and CF are lexically very close, and most of their difference could be described on the syntactic level (KINGLER; PICONE; VALDMAN, 1997). Furthermore, many speakers employ both varieties, switch them and mix them, so that Valdman (1997, p. 5) considers it difficult "to determine who speaks what to whom in which situation and to what end".

For some scholars, the distinction is based more on social and racial criteria than on linguistic ones. Historically, LC is linked to slavery and has been referred to with racist terms such as français nèg, or couri vini (VALDMAN; KLINGLER, 1997, p. 110). Although there are some White people who speak LC, as well as there are Black people who speak CF, the distinction seems to remain a socioethnic matter. Dubois (1997, p. 54) also observes, that distinguishing CF and LC "inevitably has racial correlates". Banzar corroborates this view and even claims that: "The social hierarchy creates the linguistic hierarchy" 4 (2010, p. 1834) and proposes the following figure to illustrate the correlation between socioethnic stratification and linguistic representations' hierarchization until the $\mathrm{XIX}^{\text {th }}$ century. The hierarchy of linguistic representations parallels, while not perfectly, the socioethnic stratification:

4 La hiérarchie sociale crée la hiérarchie linguistique. 
$\underline{\text { Socioethnic stratification }}$

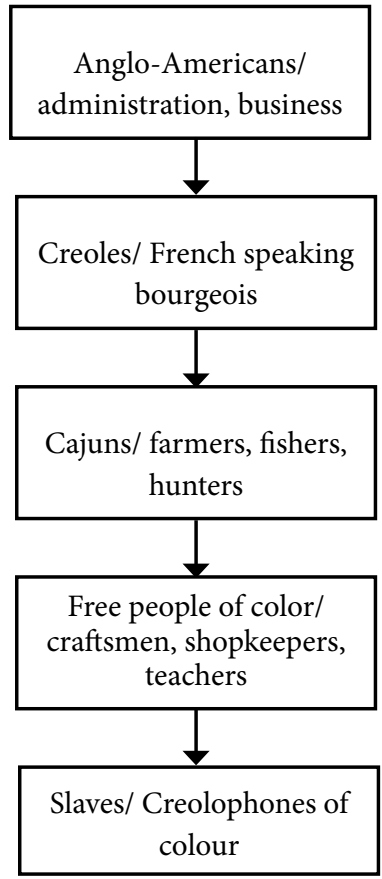

Hierarchization in the $\underline{\text { linguistic representations }}$

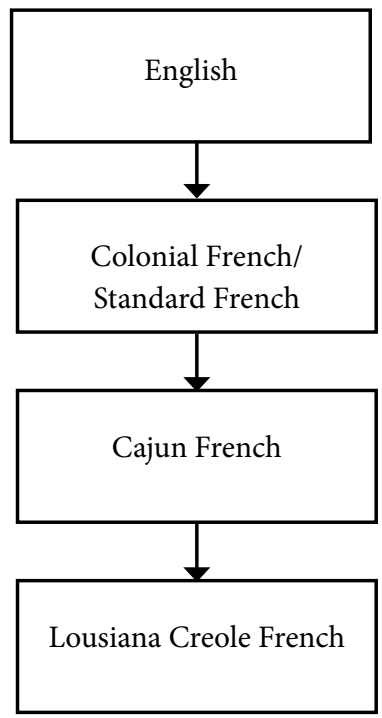

Figure 1: Socio-ethnic stratification and hierarchization in the linguistic representations of the Louisiana population in the XVIII ${ }^{\text {th }}$ XIX ${ }^{\text {th }}$ centuries (BANZAR, 2010, p. 1834-1835).

The position of "Colonial French / Standard French" in Louisiana is debated by some linguists. Picone and Valdman, who prefer the term "Plantation French" to "Colonial French", reject the tripartite variety model presented earlier and argue that the "Plantation French" was very close to what is now called "Standard French", since the Creole elite always maintained contacts with the "motherland" (ATRAN-FRESCO, 2014, p. 97). The written code of Colonial French did not differ from Standard French. However, this variety was limited to a very small urban elite, until 
its presence faded away, more or less in the first half of the $\mathrm{XX}^{\text {th }}$ century.

At the end of the 1960s, during the revitalization movement, Louisianan institutions attempted to reintroduce Standard French, through schools, in the region, on a much larger scale than the urban nucleus where it had once been present. According to Valdman and Klingler (1997), its introduction in schools has complicated the linguistic situation in Louisiana. The fact that a difference between "Louisiana French" and "Standard French" is made is somehow symptomatic. It shows that the French spoken in Louisiana is perceived as being different from other varieties, and particularly from SF. In order to describe the complex linguistic situation of Louisiana, Valdman and Klingler, as other linguists, prefer to speak of a "continuum":

ranging from a basilectal pole formed by the type of Creole that is structurally most distant from French to an acrolectal pole formed by CF, Colonial French, SF, or even English, depending on the perspective taken. Between these two poles lies a series of intermediate varieties that, according to the features they bear, may be situated closer to one or the other end of the continuum. (VALDMAN; KLINGLER, 1997, p. 154).

Nevertheless, the situation of Louisiana French remains very different from the French from France, due to its specific linguistic situation, typically, a diglossic one, as defined by Ferguson (1959) and Fishman (1967). English occupies the position of the $\mathrm{H}$-variety, being a standard language used in all public and formal domains, and LF the L-variety, remaining non-codified and used only in the informal, private, sphere, among friends and family. However, the presence of several French varieties of different levels of prestige has led to a situation characterized by Valdman (1997) as a multiple embedded diglossia (diglossie enchâssée). At the top of the scale, English, the dominant language, is present in all the domains and enjoys 
the highest prestige, thereafter would come SF, introduced lately in the region, and, at the bottom of scale, the two local varieties, CF and LC, the latter being the less valorized language. The situation can be schematized as follows:

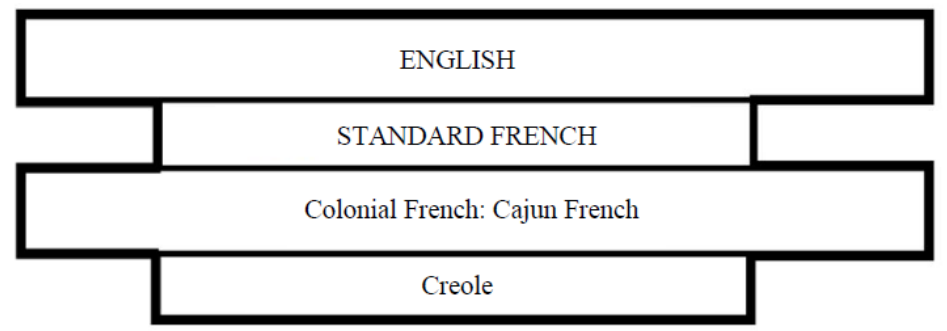

Figure 2: Embedded diglossia in Louisiana. (Valdman, 1996, p. 155 apud Atran-Fresco, 2014, p. 99).

During the revitalization movement and the introduction of French classes in schools, many debates were oriented by the question of whether to teach SF or a vernacular variety, in particular CF. As noted by Valdman (1997), LC was barely mentioned in these discussions. However, before analyzing this process, we will take a closer look at the notion of "standard language" in order to understand what is meant by "Standard French".

\section{The notion of standard language}

As mentioned above, at the eve of the revitalization movement, the sociolinguistic situation in Louisiana was a complex one. As Valdman points out, the introduction of SF even complicated the situation.

Since the first works of Labov and the emergence of variationist linguistics, it is recognized that what we call "language" is a heterogeneous and variable object. Languages vary on many aspects (phonetics, morphology, lexicon, syntax, etc.) and variation is one of their intrinsic 
characteristics. We also know that variation is much more present in the spoken language than in the written one. Yet, most speakers generally have a very clear view of what is considered "correct" or "incorrect" in their language(s). In the case of standardized languages, this vision is strongly influenced by the official written code, as Brown (1997, p. 218) points out: "[...] it is the written code that is viewed as the model of correctness in practice". Indeed, the written norm traditionally enjoys a higher prestige than the spoken one. And, very often, the criterion of "correctness" in the sense of standard norms is extended to non-standards, which are, hence, seen as “incorrect” (PRESTON; ROBINSON, 2005, 22).

The standardized written form of a language represents what Bagno calls a "language as a hypostasis", that is to say, a language, an abstract reality, that went through a process of objectification, and thus became a concrete reality. According to him: "The process of standardization grasps the language and removes it from its intimate, private, community life and transforms it into an institution, a cultural monument, tied to a national policy and, on several occasions throughout history, an imperial, colonial policy"6 (BAGNO, 2011, p. 359). To corroborate this vision, we assume that the "standard" language constitutes a representation of the language - rather than the language itself - that embodies it into a tangible object, in a similar way that a map objectifies space, or a clock, time, two abstract notions that may be as hard to define as the one of "language". In a way, we take language as a "vis-à-vis", as an object of reflection, and, thus, as a matter of planning and editing, by means of a written variety.

A written standard language is usually an object easy to identity, as its rules and properties are generally registered in grammars and dictionaries.

\footnotetext{
5 Língua como hipóstase.

6 O processo de padronização agarra a língua e a retira de sua vida íntima, privada, comunitária e a transforma numa instituição, num monumento cultural, em vínculo de uma política nacional e, em várias ocasiões ao longo da história, de uma política imperial, colonial.
} 
This is very clear in the case of French, for this language is often taken as a prototypical example of highly standardized languages, as many institutions are in charge of defining its rules (i.e. the often cited Académie française). However, it is much harder to qualify what a standardized spoken language is, as Milroy and Milroy (1999, p. 19) state: "absolute standardization of a spoken language is never achieved (the only fully standardized language is a dead language)". Indeed, the inherent variation character of spoken language makes it impossible to be fully standardized, as variation and standardization are, by nature, antinomic. That is why the authors refer to "standardization as an ideology", pointing out that, never being achieved, standardization exists as "an idea in the mind rather than a reality". In this perspective, a standard language is "a set of abstract norms to which actual usage may conform to a greater or lesser extent" (MILROY; MILROY, 1999, p. 19). This meets Bagno's assumption that standard language is not a language variety, as it is spoken by no one: "[...] mother tongue of no one, paternal language par excellence, language of the law, a norm in the most legal sense of the word"7 (BAGNO, 2011, p. 367).

Considering this, what are we talking about when we mention "Standard French"? The very definition of Standard French remains, thus, problematic. In the Louisianan context, it usually refers to the variety introduced in the schools in the 1960s. In the literature about Louisiana French, the expressions International French, General French, Referential French or Normative French can be found to describe the French language introduced in the region from the 1960s-1970s, particularly in schools. Brown (2005) prefers the term "French of France". According to her: “[...] if we continue to use standard French to indicate FF [French from France], this implies that francophones of the non-hexagonal francophonie are

7 Língua materna de ninguém, língua paterna por excelência, língua da lei, uma norma no sentido mais jurídico do termo. 
non-standard, that is, inferior. In fact, each regional variety is legitimate."8 (BROWN, 2005, p. 389 apud ATRAN-FRESCO, 2014, p. 104). Thus, the use of the term standard French would imply an inferiorization of the speakers outside of France, among them, Louisiana speakers of French.

Albeit the term FF is of interest to valorize the local varieties of Louisiana, its definition presents some flaws on the descriptive level, as it both eludes the diversity of the French language spoken in France and the proximity between some varieties across the Atlantic. First, the use of the term "French of France" to refer to "Standard language" remains unclear to which "French of France" it refers. Does it mean the written form? In that case, the use of such a term would be inappropriate as the written norm only reflects partially the spoken varieties of a language. And if it refers to the spoken language, which variety? Only the prestige variety of the educated Parisian elite? Or also the regional ones? The use of "French of France", as a substitute to "Standard French", suggests that it rather refers to the prestige variety, and thus provides only a partial view of French varieties spoken as a whole in France, restricting it to a very small and located portion of speakers.

Moreover, the term suggests a strong difference between the varieties found in Louisiana and in France. There are many attested specificities of the French language spoken in Louisiana, as a result of centuries with no contacts between the two territories. But those differences should not occult the fact that there are also many similarities between Louisiana French and varieties of French from other territories, mainly Quebec and western France. For instance, it is very striking to observe that some features commonly labeled as specific to Cajun French are also used in some varieties of regional French. As an example, we can quote the interrogative

8 Si l'on continue à utiliser le français standard pour indiquer le FF [français de France], cela implique que les francophones de la francophonie non hexagonale sont non standards, à savoir inférieurs. Dans les faits, chaque variété régionale est légitime. 
qui having the meaning of que (ex: Qui que tu dis ?), the use of the verb brailler to mean "to cry" (SF: "to yell"), or mouiller to mean "to rain" (SF: "to wet"), words that are present in the Cajun variety, but also appear as examples of a regional variety spoken in the rural areas of High Brittany in a study conducted by Trehel and Blanchard (2003). This indicates some common features between LF and varieties spoken in France and corroborates Ancelet's view, that "CF does not differ from 'standard' French any more than do other regional variations of the French language among speakers of comparable social and cultural background" (ANCELET, 1988 apud LINDNER, 2018, p. 45).

Due to the unclearness of the term "French of France", we prefer to use "Standard French", following Valdman's definition, a representation of the language that reflects an ideology rather than transcribes an observable reality, "an idealized view of the language behavior of a particular group of speakers, in this case the cultured members of the Parisian bourgeoisie and the French people with close social ties to this group"9 (VALDMAN, 2000 apud ATRAN-FRESCO, 2014, p. 103). We prefer to use the word Louisiana French to refer to the continuum of varieties of French spoken in Louisiana (Creole, Cajun, etc.) and French of France to refer to the group of varieties spoken in France (Parisian, but also Meridional French, argot, etc.), being Standard French present as a common written code in both territories.

Another interesting classification to describe the question of the norm is the distinction made by Milroy and Milroy (1999) between social norm and community norm. The social norm refers to "the kind of norm of which speakers are explicitly aware and which refers to the wider social acceptability of linguistic variants" (MILROY; MILROY, 1999, p. 92) whereas the community norm is another type of norm, in contradiction

9 Une vision idéalisée du comportement langagier d'un groupe particulier de locuteurs, en l'occurrence les membres cultivés de la bourgeoisie parisienne ainsi que les Français ayant des liens sociaux étroits avec ce groupe. 
with the social one, linked to the community's identity. Brown (1997) mentions that in Louisiana, SF acts as the social norm, that is to say, the one seen as "the correct language", whereas Louisiana French would be the community norm, linked to a regional and social identity, making it "our language". This distinction applies indeed very well to the case of Louisiana, as the opposition of those two types of norms which have been present since the beginning of the revitalization movement.

Until today, the standard used in Louisiana is strongly influenced by the one used in the rest of the francophone world. However, there have been some attempts to create a new standard that would be closer to the spoken varieties in Louisiana. Although it has not led to the creation of a fully institutionalized new norm, that would have led to the establishment of a "Standard from Louisiana" and a "Standard from France", it has influenced the actual language policies in Louisiana. This process will be the object of the next section.

\section{The revitalization movement and the debate on norm in}

\section{Louisiana}

Standard French as language of instruction in school recently arrived in Louisiana, in the late 1960s, when a revitalization process began. The Cajun revitalization movement has the particularity of having been launched by an institutional decision, instead of being initiated by a grassroots movement, and mainly relied on schools. At that time, there was a harsh debate on the kind of French that should be used in the revitalization process.

It is a fact that the choice of a variety and the standardization activity often constitute the first steps of a language policy. This is what suggests the model proposed by Haugen in 1983, and resumed as follows by Calvet (2007): 


\begin{tabular}{|l|l|l|}
\hline & $\begin{array}{l}\text { Form } \\
\text { (language planning) }\end{array}$ & $\begin{array}{l}\text { Function } \\
\text { (language cultivation) }\end{array}$ \\
\hline $\begin{array}{l}\text { Society } \\
\text { (status } \\
\text { planning) }\end{array}$ & $\begin{array}{l}\text { 1. Choice } \\
\text { (decision process) } \\
\text { a) problem identification } \\
\text { b) norm selection }\end{array}$ & $\begin{array}{l}\text { 3. Implementation } \\
\text { (educational process) } \\
\text { a) Correction } \\
\text { b) Evaluation }\end{array}$ \\
\hline $\begin{array}{l}\text { Language } \\
\text { (corpus } \\
\text { planning) }\end{array}$ & $\begin{array}{l}\text { 2. Codification } \\
\text { (standardization) } \\
\text { a) grafic transcription } \\
\text { b) syntax } \\
\text { c) lexicon }\end{array}$ & $\begin{array}{l}\text { 4. Modernization } \\
\text { (functional development) } \\
\text { a) terminology modernization } \\
\text { b) stylistic developement }\end{array}$ \\
\hline
\end{tabular}

Figure 3: Haugen's model (CALVET, 2007, p. 30-31).

As we can see, Haugen based his model on the distinction between status planning and corpus planning, that he borrowed from Kloss (CALVET, 2007, p. 29). Corpus planning refers to interventions on the formal aspect of the language (writing system, standardization, etc.) whereas the status planning refers to interventions on the social status of the language, its visibility and its prestige (for instance, making it official or introducing it in schools). Both can be exerted on the society level or on the language itself. Regarding the corpus planning, Calvet refers to the "languages equipment" 10 to mention the instruments developed to give languages new functions (writing system, neologisms, grammar, etc.)

In the case of LF, although there were some attempts to standardize the language, the process remains unfinished. As Brown (1997, p. 224) states: "If the stages of the implementation of language-planning strategies are reconsidered, the first step, the selection of a norm, is already a thorny and unresolved issue in Louisiana”. Indeed, this issue exists since the creation of the CODOFIL (Council for the Development of French in Louisiana), an institution created in 1968 by a vote of the Louisiana Legislature, aiming

10 equipamento das línguas. 
at promoting the reintroduction of French in the State. Several acts were passed to support French language teaching, to train French teachers, to establish a French language television and encourage the use of French in public documents. The creation of the CODOFIL is often connected to the dedication of one man, James Domengeaux, an attorney and influential politician of the state of Louisiana. Born in a family of Cajun background, he espoused the cause of preserving the French Language in Louisiana and became the first chairman of the CODOFIL. His main motivation was to restore a bilingual Louisiana, particularly through the reintroduction of the French language in schools. He would have declared the famous sentence that later became the slogan of the CODOFIL: "Schools have destroyed French, schools must restore it" (HENRY, 1997, p.190). In fact, since the beginning, the main activity of the CODOFIL has been to support the presence of the French language in public schools of Louisiana.

However, this decision has not been well received by the Cajun communities and aroused controversies. A vivid polemic appeared on the target language itself. To teach "French" and restore the "French language" in Louisiana was the stated purpose, but which kind of "French" was this plan about? As previously mentioned, at least two local varieties could be identified (CF and LC). At that time, both varieties were highly stigmatized in Louisiana and LF as a whole was of low-prestige. However, at that time, "French" was also a language present in other parts of the world where it benefited from a high prestige and was already standardized. Barnett (2018, p. 145) sums up the situation: "The linguistic situation of Louisiana is unique in many ways; one distinguishing characteristic is the stigmatized language in question. French is a world language and has prestige outside of the state of Louisiana".

Domengeaux opted to introduce SF in schools, to the expense of CF, and LC was barely mentioned in the debates. One of the main arguments for choosing SF was that it would help Louisiana to be less isolated and 
to connect the region to the Francophone world, and, therefore, open it to international business and diplomacy. According to Domengeaux, SF would be "the key to one of the greatest universal cultures" (HENRY, 1997, p. 189). In Domengeaux's perspective, it is clear that the fact that Cajun French was not standardized would hinder its teaching: "Why should we perpetuate illiteracy in the classroom by teaching Cajun French? It's an oral language. It doesn't have any grammar. It doesn't have a written form" (ANCELET; LAFLEUR, 2005, p. 416 apud ATRAN-FRESCO, 2014, p. 100). However, Domengeaux did not only prefer SF for its practical advantage, but also because he had a highly negative view of CF and saw it as unappropriated to use it in schools: "Do we teach redneck English? We cannot teach anything but standard French if we want to save this language" (HENRY, 1997, p. 189).

This radical attitude against CF was received as an offense to Cajun communities, and the CODOFIL and the teaching program of French met opposition at its beginning. Although the CODOFIL had created the Comité du Français Louisianais, which was in charge to "formulate a philosophy for the standardization of LF and norms for orthography" (BROWN, 1997, p. 225), it did not really lead to a full standardization and the CODOFIL based its policy mostly on SF.

According to Henry (1997), the choices made by the CODOFIL triggered a strong opposition that led to the constitution of a grassroot movement in Louisiana. The imposition of SF in the schools has been regarded as disrespect of the Cajun and Creole populations. Consequently, many individuals from different backgrounds got involved in the so-called "French renaissance" in Louisiana and produced songs, theater pieces, books, etc., in CF and in LC. Barry Jean Ancelet (2018), who was one of the main actors of this movement, under his pen-name Jean Arceneaux, states that it was rather a naissance (birth) than a renaissance (rebirth), since many of the cultural productions of this period were actually the firsts ever 
made in CF.

The rejection of SF also led several activists to propose a codification of CF. This was for instance suggested by James Faulk, a French teacher who, in 1977, for pedagogical purposes, drew a first proposition of orthography, 'san English-based phonetic transcription:

Ō̄ trahvars lah reevee-ar Meeseeseepee poor ahreevā Iaw.
On traverse la rivière Mississippi pour arriver là.

On traverse le fleuve du Mississippi pour y arriver (pour arriver là-bas)

We cross the Mississippi River to get there.

Figure 4: Faulk's proposition of Cajun French orthography (ATRAN-FRESCO, 2014, p. 104).

However, his proposition was not retained for use in schools and generated strong controversies, as it was more a transliteration of $\mathrm{CF}$ with the English conventions than an actual new norm. James Domengeaux, who was the director of the CODOFIL at the time, firmly rejected this proposition. In her thesis, Atran-Fresco (2014) presents a newspaper's extract that illustrates the terms of the debate:

Faulk said he wrote his textbook because youngsters are learning French in school but still can't talk with their grandparents. "What we're trying to do is preserve our heritage. We Cajuns are paying hard earned tax money and that money is given to Domengeaux to help obliterate [our] own language [...]. I represent the people who work in the rice fields, the people who fish the bayous", Faulk said. "We don't want standard French to be stopped in the schools. We simply want them to add Cajun French to the curriculum and give the children a chance to choose. [...] "Cajun French is an oral language and it has all the imperfections of an oral language", Domengeaux said. Daily News, 6 avril 1979. (ATRAN-FRESCO, 2014, p.105-106). 
Another attempt, also analyzed by Atran-Fresco, is the Vernaculiterary Cajun, a proposition of standardization made by an anonymous author who sent it to a local radio station in 1983. The author made some suggestions to write the Cajun grammar (see figure 5) and some words, and translated a text in Cajun French:

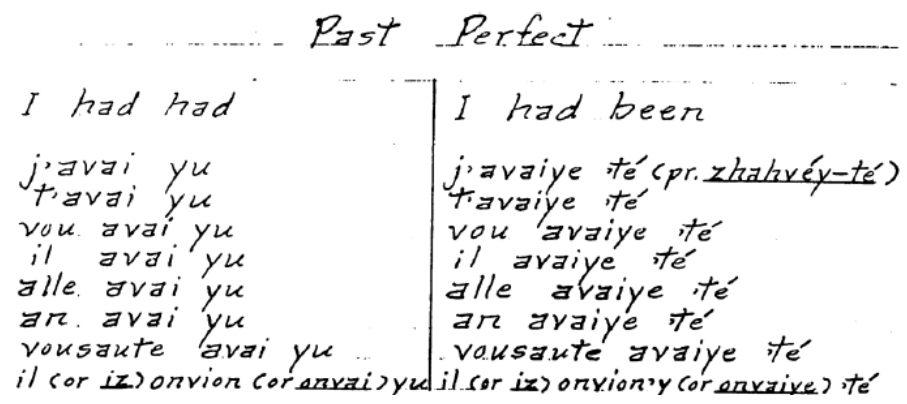

Figure 5: conjugation of the verb avoir (to have) proposed in the Vernacu-literary Cajun (extract) (ATRAN-FRESCO, 2014, p. 110).

Together with the texts in Cajun French, the author sent a note in which (s)he exposed his/her point of view on the norm to be used in Louisiana:

"Let me try to get to y'all this way: Parisian French, English, and all of the modern major languages are to some extent artificial. That is to say decisions were made by academicians to arrest their natural evolution. Except for an increase in vocabulary, Parisian French and English have but little changed since the 1700 's. Cajun, on the other hand, has been free to unfold in accordance with the articulatory tendencies and grammatical preferences of the mostly isolated farmers and fishermen on which it is based. [...] And no, I do not approve of any Codofil-certified priests who write Codofil certified so-called Cajun dictionaries. Will they write the entries the way we pronou- 
nce them? Will they leave out final consonants that no longer cause linking in Cajun but do in Parisian? Case closed. And case closed to the teaching of $\mathrm{Pa}$ risian in the schools for which there is no feeling by Cajun children. One can tell it's because they feel no kinship towards an imported dialect unknown to their parents and grandparents." (ATRAN-FRESCO, 2014, p. 108)

This extract is particularly interesting, as it illustrates some of the issues raised about standard language. First, it shows the opposition of the population, who perceived the language promoted by the CODOFIL as "not theirs". It meets Brown's (1997) analysis that SF, or even the standardization proposed by the CODOFIL, does not act as a community norm, as there is "no feeling" "no kinship" towards it. Second, the author is fully conscious of the fact that "modern languages", that is, standard languages, are "artificial", that is to say that they are artifacts, or, to paraphrase Marcos Bagno, they are hypostasis. The author of the letter underlines very well the static nature of standard languages, in opposition to the variable nature of spoken ones ("free to unfold [...]"). Finally, it is worth noting that, in the words of the author, SF is actually referred to as "Parisian French", underlying the fact that standard languages are often created from the variety of the prestige group of the society. It also corroborates Valdman's definition of Standard French, mentioned above in this article.

However, those propositions were not retained and a more conciliating option has finally been adopted. The current graphic representation is qualified by Atran-Fresco $(2014$, p. 96) as a "compromise of norms"11. The current graphic representation, according to Valdman (1996, p. 161 apud ATRAN-FRESCO, 2014, p. 112), takes into account

11 Compromis de normes. 
phonological, morphosyntactic and lexical specificities of LF, while adopting the orthographic conventions of SF. The Dictionary of Louisiana French (2010) is a good illustration of this negotiation. The writing system is similar to SF, but it also registers the specificities of LF on many levels, i.e.:

- Pronunciation: ex. Amaricain (English: "American"; SF: "Américain"),

- Neologism: ex. traduiseur (English: "translator";SF: "traducteur")

- Borrowing: ex. trash (English: "trash"; SF: "ordures").

Thus, it adopts the transcription system used in SF, adapting it to the specificities of LF.

\section{Final considerations}

We saw that Louisiana has a unique sociolinguistic landscape and that it is not easy to define the varieties of French spoken in the State. During the revitalization movement, the language has been at the center of identity revindications and became one of the issues at the forefront of the movement. In particular, there have been strong debates about the variety to be taught in the schools, some preferring SF, others, CF. The top-down imposition of SF had a strong negative impact in the Cajun community, but it also triggered revindications of an own standard. It encouraged some members of the community to act on their own language and propose their own normalization, sometimes in a very creative way. The present situation is one of compromise, with a norm constantly oscillating between SF, an abstract and normative vision of the language, and CF, the local variety more bound to speakers' identity. This negotiation has been practiced in schools, where SF is no longer the only language taught, but share the space with CF. This process is called "Louisianification of the teaching" 
(BARNETT, 2018).

\section{References}

ANCELET, Barry Jean. Lexception cadienne et créole en Louisiane. In: PRICE, Joseph Edward (Org.). La jeune francophonie américaine. Paris: L'Harmattan, 2018. p. 121-140.

ATRAN-FRESCO, Laura. Les Cadiens au présent: Revendications identitaires d'une population francophone en situation minoritaire. 2014. 367 f. Tese de doutorado. University of Louisiana at Lafayette, Lafayette, 2014.

BAGNO, Marcos. O que é uma língua? Imaginário, ciência e hipóstase. In: LAGARES, Xóan Carlos; BAGNO, Marcos. Políticas de norma e conflitos linguísticos. São Paulo: Parábola, 2011.

BANZAR, Chimegsaikhan. Les variétés du français en Louisiane et leur statut sociolinguistique. In: CONGRÈS MONDIAL DE LINGUISTIQUE FRANÇAISE, 2010, Paris. Anais [...]. Paris: Institut de linguistique française, 2010. p. 1831-1837.

BARNETT, Brian. The Louisianification of the French immersion classroom in the state of Louisiana: how can it be done? In: PRICE, Joseph Edward (org.). La jeune francophonie américaine. Paris: L’Harmattan, 2018. p. $141-160$.

BLYTH, Carl. The Sociolinguistic Situation of Cajun French: The Effects of Language Shift and Language Loss. In: VALDMAN, Albert (org.). French and creole in Louisiana. New York: Springer, 1997. p. 25-46.

BROWN, Becky. The Development of a Louisiana French Norm. In: VALDMAN, Albert (org.). French and creole in Louisiana. New York: 
Springer, 1997. p. 215-236.

BRUCE, Clint. Translations of Jean Arceneaux. Equinoxes, n. 2, 2004.

CALVET, Louis-Jean. As políticas linguísticas. São Paulo: Parábola, 2007.

DUBOIS, Sylvie. Field Method in Four Cajun Communities in Louisiana. In: VALDMAN, Albert (org.). French and creole in Louisiana. New York: Springer, 1997. p. 47-70.

HENRY, Jacques. The Louisiana French Movement: Actors and Actions in Social Change. In: VALDMAN, Albert (org.). French and creole in Louisiana. New York: Springer, 1997. p. 183-214.

KLINGLER, Thomas; PICONE, Michael; VALDMAN, Albert. The lexicon of Louisiana French. In: VALDMAN, Albert (org.). French and creole in Louisiana. New York: Springer, 1997. p. 145-182.

LINDNER, Tamara. Les jeunes Louisianais et les français cadien : quels rapports? In: PRICE, Joseph Edward (org.). La jeune francophonie américaine. Paris: L'Harmattan, 2018. p. 45-64.

MILROY, James; MILROY, Lesley. Authority in language. Investigating standard English. London: Taylor and Francis (3 ${ }^{\text {rd }}$ edition), 1999.

PRESTON, Dennis R.; ROBINSON, Gregory C. Dialect Perception and Attitudes to Variation. In: Ball, Martin J. (Org.). Clinical Sociolinguistics. Oxford: Wiley-Blackwell, 2005. p. 133-150.

RIOULT, N. Louisiana French: A successful Revitalization?. In: SAVEDRA, M.; ROSENBERG, P. Estudos em sociolinguística de contato, forthcoming.

TABOURET-KELLER, Andrée. Language and Identity. In: COULMAS, 
Florian (org.). The Handbook of Sociolinguistics. Malden : Blackwell, 1997. p. 315-326.

TREHEL, Nathalie ; BLANCHET, Philippe. Pratiques linguistiques régionales délèves du primaire et de collège en zones suburbaines de Bretagne gallo. Premiers résultats d'enquêtes. In: BILLIEZ, Jacqueline (org.). Contacts de langues, modèles, typologies, interventions. Paris, L'Harmattan, 2003, p. 61-78.

VALDMAN, Albert (org.). French and creole in Louisiana. New York: Springer, 1997.

; KLINGLER, Thomas. The Structure of Louisiana Creole. In: VALDMAN, Albert (org.). French and creole in Louisiana. New York: Springer, 1997. p. 109-144.

; ROTTET, Kevin. (org.). Dictionnary of Louisiana French. Jackson: University Press of Mississippi, 2010.

O processo de padronização do francês luisianês: questões e resultados

Resumo: O principal objetivo deste artigo é dar uma visão geral sobre o processo de padronização da língua francesa na Luisiana. Depois de examinar a situação sociolinguística do francês da Louisiana e discutir a noção de "língua padrão", seguindo as definições de Bagno (2011) e Milroy \& Milroy (1999), tentaremos entender o que abarca a noção de "francês padrão". Em seguida, analisaremos como sua introdução na Louisiana desencadeou algumas questões sobre a norma linguística a ser usada durante o movimento de revitalização, que começou na década de 1960, e como esses debates influenciaram a norma francesa usada hoje em dia na Louisiana.

Palavras-chave: Lingua-padrão. Norma linguística. Francês Luisianês. Revitalização.

Recebido em: 01/11/2020

Aceito em: 28/05/2021 